\title{
Deciphering the structure of living beings
}

The Birth of the Cell

by Henry Harris

Yale University Press,

New Haven and London 1999

First published in paperback May 2000.

$\mathfrak{E} 11.95, \$ 17$

Paolo Mazzarello

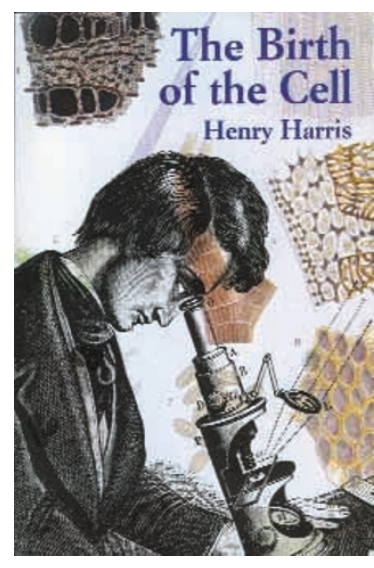

T

he imaginative power of nature certainly could not have produced anything more flexible than the cell to account for every complex morphology of the organic world. In the same way that the seven notes of the scale generate all possible musical composition, cells embedded and linked together produce the strange fractal living shapes we see everywhere. It was not easy, however, to reach this unitary concept of life and in fact it took more than two hundred years after the microscope had been invented at the beginning of the seventeenth century.

In The Birth of the Cell, Henry Harris, Regius Professor Emeritus of Medicine at the University of Oxford, narrates the history of the extraordinary intellectual adventure that led us to consider the cells as the basic bricks of living organisms. Digging into the many scientific, historical and philosophical intricacies of the subject, and going back to the primary sources with the relevant passage often translated for the first time in English (but reported in the original language in the useful appendix), Harris vividly portrays an exciting history of discoveries, theoretical synthesis and transmission of ideas, but also of false ways, misinterpretations of experimental data, personal idiosyncrasies, national pride, and political and social friction among scientists throughout Europe. On the whole, Harris's book is very informative and it amends a lot of errors and misconceptions of the previous assessment of the early history of cytology and histology. By the end the reader will have acquired an extremely detailed idea of the origin of every fundamental contribution in the conceptual edifice of cell theory.

The history of cell theory, as properly depicted by Harris, is the history of two fundamental themes that emerge throughout the book. The first is the homology between unicellular and multicellular organisms and the second is the structural homology between plants and animals.

Unicellular organisms, in which life could be imagined on the basis of their motility, were discovered in the seventeenth century by the Dutch microscopist Antoni van Leeuwenhoek. These 'little animals' were subsequently seen in vegetable and animal infusions and for this reason named 'infusoria'. It was more difficult to reduce the multicellular organisms to their basic elements, although the English physicist Robert Hooke discovered single cells in the living plant as long ago as 1665, when he discovered, in thin sections of cork, microscopic cavities enclosed in a tridimensional net of walls. Given their analogy with cubicules or small rooms, the Latin for which is cella, Hooke applied the term cell to these empty spaces. It remained in literature and eventually became the eponym to indicate the basic unit of life, even if Hooke used the word differently to later biologists (he thought of the cork cells as passages for 'natural juices' of the plant). Harris points out that it was not until 1805 that the biologist Lorenz Oken had the prescient intuition of the fundamental homology between the 'little animals' of Leeuwenhoek and the multicellular organisms (such as the cork studied by Hooke) according to which aggregates of cooperating 'infusoria' become living tissue. But, as Harris observes, this extraordinarily prophetic vision remained uninfluential because it was far too early for the scientific community of the time, and it was more than thirty years before it became common among biologists.

That plants and animals are homologous in structure was similarly difficult to grasp, and appreciation of this fact was not a sudden and single acquisition but the result of decades of scientific endeavour. Harris gives a systematic evaluation of the contributions of biologists such as Purkinje, Valentin, Rusconi and Dumortier, whose studies, in the context of cell theory, are not generally fully recognized in standard textbooks. A substantial revision has been made by Harris in considering the dramatic generalization of cell theory
...By the end the reader

will have acquired an extremely

detailed idea of the origin of

every fundamental contribution

in the conceptual edifice of

cell theory...

(1838-9) to which the names of Schwann and Schleiden remained attached. These biologists generalized the concept that plants and animals are composed of cells with a similar nucleus and nucleolus, and that the process of formation of cells is the basis of the development of organisms. However, their theory was wrong from a physiological point of view, as they thought the new cells develop by a sort of 'crystallization' around a nucleus, with progressive enlargement of this 'condensed' material.

Harris's hero is clearly Robert Remak (another scientist not acknowledged in his lifetime nor adequately recognized even now, as Harris points out) who disproved the theory of Schwann and Schleiden and demonstrated that new cells aris by a process of binary scission from pre-existing cells. In the second half of the nineteenth century the cell theory (or cell doctrine as Harris calls it in the last paragraph of the book) reached its definitive form. It was at this time that the prophetic intuition of Goethe - "every living being is not a single but a plurality; even if it presents itself as an individual it remains however a whole of autonomous and living beings" (Die Absicht Eingeleitet, 1807) - found its definitive confirmation.

Paolo Mazzarello is in the Istituto di Genetica Biochimica ed Evoluzionistica, CNR , 27100 Pavia, Italy e-mail:mazzarello@igbe.pv.cnr.it 